\title{
Nick Hales: an appreciation of his life and work
}

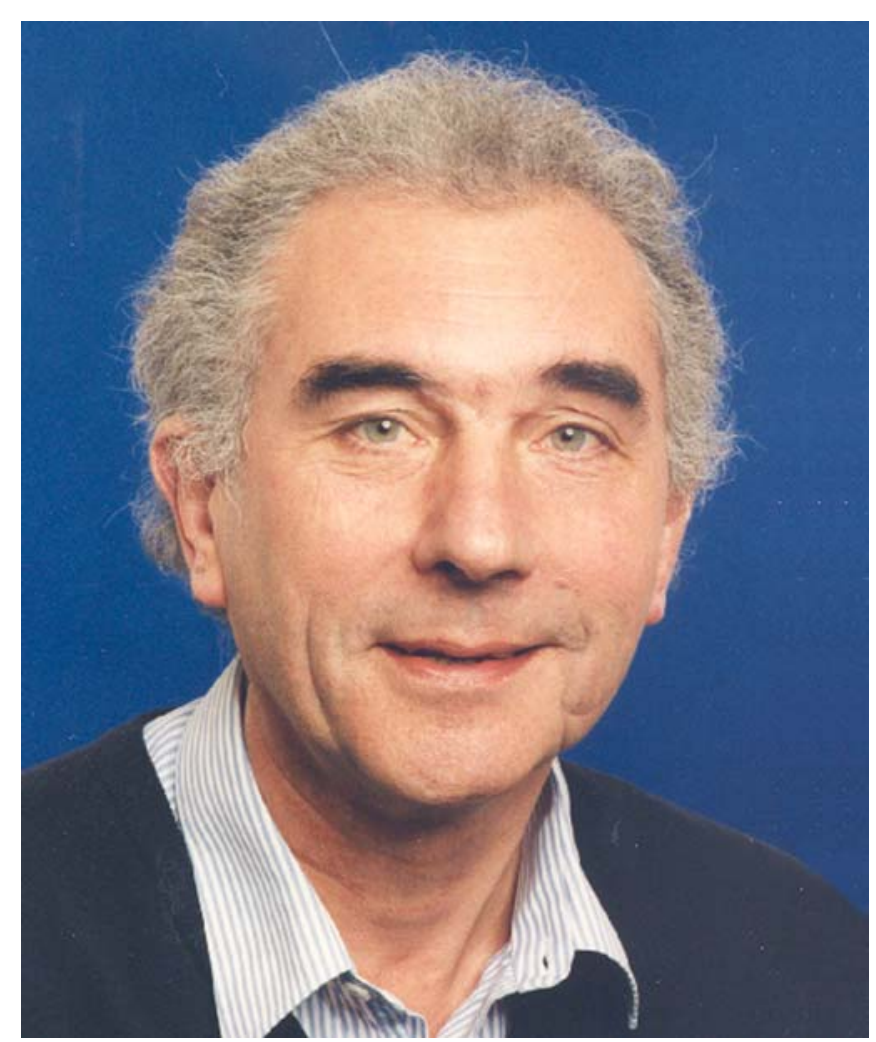

Professor Charles Nicholas (Nick) Hales M.A., M.D., Ph. D., FRCPath, FRCP, FMedSci, FRS was, for 40 years, a leading figure in UK biomedical research. During a distinguished career he made major contributions to the development of methods for measuring hormones such as insulin, to understanding the mechanism of insulin secretion, and to elucidating the role of nutrition during early life as a key factor in the development of diabetes in adulthood.

Nick was born in Stafford in 1935, into a medical familyhis father, Walter, was an oral surgeon. He was evacuated to Canada during the war, an experience he often recalled even though he had only been a young child at the time.

K. Siddle $(\bowtie) \cdot$ J. P. Luzio $\cdot$ S. E. Ozanne

Department of Clinical Biochemistry, Addenbrooke's Hospital, University of Cambridge,

Cambridge, CB2 2QR, UK

e-mail: ks14@mole.bio.cam.ac.uk
He was educated at King Edward VI Grammar School, Stafford, and then followed his brother, Tim, to Trinity College, Cambridge to read medicine, choosing to study biochemistry in his third year. There was of course no clinical medical course at Cambridge in those days, and Nick undertook his clinical training at University College Hospital, London. After completing his house jobs, he returned to Cambridge in 1960 to study for a Ph.D. in biochemistry in the laboratory of Philip (later Professor Sir Philip) Randle. At that time the Department of Biochemistry, under Sir Frank Young, had a strong interest in the control of metabolism, particularly in the actions of growth hormone and insulin. Nick's own interest in diabetes first arose because both his mother, Phyllis, and younger sister, Judith, had developed the disease, as Nick himself was to do later in life.

Although almost 40 years had elapsed since the discovery of insulin by Banting and colleagues in Toronto, when Nick began his Ph.D. the biochemical mechanisms underlying insulin secretion and action remained a mystery. A major technical breakthrough in 1960 had been the description by Yalow and Berson of an immunoassay method employing insulin antibody and radio-iodinated insulin [1], which had the sensitivity and specificity needed to determine insulin concentrations in blood plasma or isolated islets of Langerhans. Nick was very quick to appreciate the significance of this technique; he developed a modification of the immunoassay method that greatly facilitated its application and led to its widespread use. Where others had used electrophoresis or fractional precipitation with salts to separate antibody-bound from free insulin before quantitation, Nick established methods employing anti-immunoglobulin to pre-precipitate the antiinsulin antibody, allowing rapid recovery of antibodybound insulin by filtration. His first major scientific paper, describing this new method, was published in The Biochemical Journal in 1963 [2], and was to become the most highly cited of the 250 original papers that followed in a prolific career. Nick's reputation was rapidly established by the widespread adoption of his immunoassay method, and his studies of circulating insulin under different pathophysiological conditions (which contributed to Randle's exposition of the glucose fatty acid cycle [3]). When Philip Randle left Cambridge in 1964 to become Professor of Biochemistry at the newly established department in 
Bristol, Nick succeeded him as university lecturer in Cambridge, though he had less than a year's postdoctoral experience at the time of his appointment. He continued to see diabetic patients in a weekly clinic at Addenbrooke's Hospital, and taught biochemistry to undergraduates at Downing College, where he was a Fellow. He was never someone who enjoyed lecturing, but at a personal level he was imaginative, sociable and immensely enthusiastic, and he soon attracted an eager band of Ph.D. students and collaborators to his basement laboratory. He was always looking to advance techniques, as well as to understand physiology and disease, and turned his thoughts to how methods for measuring insulin and other polypeptide hormones might be made even more sensitive and specific. He realised that direct quantitation of peptides by reaction with labelled antibody offered many advantages over competitive radioimmunoassay methods. He used radioactively labelled antibodies in a new format, which he termed the immunoradiometric assay, although his farsighted paper with Laughton Miles in Nature in 1968 [4] envisaged the use of enzymes or viruses as alternative labels capable of providing even greater assay sensitivity.

In 1970, Nick was appointed head of department and honorary consultant in Chemical Pathology at what was then the Welsh National School of Medicine in Cardiff. He was passionate in uniting the interests of academic research and diagnostic services under his leadership, and in expanding the role of his department, which he soon renamed Medical Biochemistry. Although his interests and responsibilities were diversifying, he continued to work on immunoassay methods, and published papers describing refinements of the immunoradiometric technique, particularly the two-site assay, which embodied a more convenient format while also ensuring specificity for intact, biologically active molecules. Nick subscribed readily to the prevailing ethos that, as the holder of an academic position and recipient of public funding, he should not seek to benefit personally from his inventions, although many of his ideas might have been patentable. He was motivated by his own scientific curiosity and a genuine desire to see rapid and widespread dissemination of technical advances to deliver maximum benefit to both scientific colleagues and patients. In fact, technical demands initially limited the application of immunoradiometric assays to a few specialised research laboratories, but this situation was short-lived. With the advent of monoclonal antibodies, first described by Köhler and Milstein in 1975, assays based on labelled antibodies (with enzymes, fluorescent or luminescent molecules as labels) came into their own as methods of choice for the quantitation of polypeptide hormones and many other analytes. Diagnostic methods based on labelled antibodies have now become a worldwide multi-billion dollar industry.

Nick returned to the University of Cambridge in 1977, as head of the Department of Clinical Biochemistry and honorary consultant at Addenbrooke's Hospital. He continued to evolve and refine methods for measuring insulin and its precursor, pro-insulin, now using site-specific monoclonal antibodies, and showed that in combination these assays could provide an early indication of the development of diabetes. However, his interests ranged widely, embracing both esoteric and practical topics, from the permeability properties of lysosomes and evolutionary origins of prohormones, to the development of cell lines with which to study insulin secretion. Indeed, he retained a strong interest in the mechanism of insulin secretion and, during a sabbatical year in Seattle in 1984, he discovered (with Dan Cook) an ATP-sensitive potassium channel in insulin-producing cells [5]. This is now recognised to be a key component in the initiation of glucose-stimulated insulin secretion and a target for sulfonylureas as glucoselowering drugs.

A fortuitous encounter with Professor David Barker, on a site visit to an MRC Unit in the Gambia in the late 1980s, set Nick off on an entirely new path. Barker told him of his striking epidemiological observations that established a link between birthweight, adult blood pressure and death from cardiovascular disease and suggested that environmental influences during foetal life play a major role in this association. Nick suspected that insulin-producing cells laid down during foetal life could also be very vulnerable to poor nutrition during this critical period, and that this might predispose to the development of diabetes in adulthood. He reasoned that the clustering of diabetes, ischaemic heart disease and hypertension in the metabolic syndrome could be explained on the basis of a common origin, poor foetal nutrition. Evidence supporting this hypothesis was quickly provided by epidemiological studies, in collaboration with Barker, on a cohort of 64-year-old men living in Hertfordshire for whom birthweight records were available. These studies demonstrated that men with a low birthweight were six times more likely to have diabetes than those with the highest birthweight [6]. These findings formed the basis of the Thrifty Phenotype Hypothesis that was put forward by Nick at his Banting Award Lecture in Dublin in 1991 [7]. His ideas initially met with considerable scepticism among a diabetes community that was focused on the search for diabetes-related genes rather than environmental origins. However, the initial epidemiological observations that Nick made with Barker have been confirmed in a large number of studies by many different laboratories, involving many different populations, and nutrition and environment in early life are now firmly established as key factors determining susceptibility to type 2 diabetes in adulthood. Nick himself used both human data and animal models to study the underlying molecular mechanisms linking foetal growth to long-term health, and in the last 15 years published around 100 papers related to the developmental origins of adult disease. He often remarked that many non-scientists had said to him that they could not understand why it took scientists so long to work out that what a woman ate during pregnancy was important to the health of her baby!

Nick made enormous contributions to academic life quite apart from his own influential research output. He was an inspirational and generous mentor, who supported younger scientists and clinical fellows by providing an intellectual environment in his departments that encour- 
aged them to tackle difficult and varied problems, develop new interests and achieve independence. He was always willing to listen and to give advice, support and constructive criticism, not least when this could be done over a beer at the end of the day! Throughout his career he enjoyed sharing new ideas with those around him and never lost his enthusiasm for science. He was always looking to break new ground, and preferred avoiding current fashion in research rather than following it. He strongly advocated the importance of combining university and NHS departments of clinical biochemistry, bringing together under one chairman those pursuing fundamental research and those involved in diagnostic assays and clinical activities. The strength of his own departments in research grant income, publications and diagnostic developments, not to mention the affection and esteem in which he was held by both his scientific and clinical colleagues, testified to his vision. He was elected a Fellow of the Royal Society in 1992 and received medals and prizes from many academic institutions and learned societies. The British Diabetic Association (now Diabetes UK) honoured him as their first R. D. Lawrence lecturer in 1970, as Banting Memorial Lecturer in 1991 and as Dorothy Hodgkin Lecturer in 2002. He won the Minkowski award of the EASD in 1971, and both his award lecture and an update some years later were published in Diabetologia [8, 9]. He was a strong supporter of European journals, and published some 40 papers in Diabetologia, provoking animated correspondence in the pages of the journal in the early days of the thrifty phenotype hypothesis. He was an Associate Editor of Diabetologia from 1979-1982, and served on the editorial boards of many other journals. Nick was no lover of administrative duties, but accepted his responsibilities and was a respected chairman of many high-level committees, including research grant review committees of the British
Diabetic Association (1978-1982), the Medical Research Council (1986-1990) and the British Heart Foundation (1992-1997). When he retired from his university position in 2002, he saw this as an opportunity to give more of his energy to research (as well as devoting more time to his favourite pastime of fishing), and he continued to maintain a vigorous research group to the end. He was particularly delighted to be asked to deliver a keynote lecture at the 2005 Keystone meeting on Diabetes and Obesity, which he saw as international recognition of his work on the foetal origins of adult disease. He is, and always will be, greatly missed by all who had the privilege of working with him.

Nick Hales, medical biochemist, was born on 25 April 1935 and died on 15 September 2005.

\section{References}

1. Yalow RS, Berson SA (1960) Immunoassay of endogenous plasma insulin in man. J Clin Invest 39:1157-1175

2. Hales CN, Randle PJ (1963) Immunoassay of insulin with insulin-antibody precipitate. Biochem J 88:137-146

3. Randle PJ, Garland PB, Hales CN, Newsholme EA (1963) The glucose fatty acid cycle. Its role in insulin sensitivity and the metabolic disturbances of diabetes mellitus. Lancet 1:790-794

4. Miles LEM, Hales CN (1968) Labelled antibodies and immunological assay systems. Nature 219:186-189

5. Cook DL, Hales CN (1984) Intracellular ATP directly blocks $\mathrm{K}^{+}$ channels in pancreatic $\beta$-cells. Nature 311:271-273

6. Hales CN, Barker DJP, Clark PMS et al (1991) Fetal and infant growth and impaired glucose tolerance at age 64 years. BMJ 303:1019-1022

7. Hales CN, Barker DJP (1992) Type 2 (non-insulin-dependent) diabetes mellitus: the thrifty phenotype hypothesis. Diabetologia 35:595-601

8. Hales CN (1972) Immunological techniques in diabetes research. Diabetologia 8:229-235

9. Hales CN (1985) Immunological techniques in diabetes research: 14 years on. Diabetologia 28:514-519 